\title{
The impact of classical massage on spine mobility
}

\author{
Radzimińska Agnieszka ${ }^{1}$, Weber-Rajek Magdalena ${ }^{1}$, Lulińska-Kuklik Ewelina ${ }^{2}$, Piecka Paulina ${ }^{1}$, Moska Waldemar ${ }^{3}$ \\ ${ }^{1}$ Nicolaus Copernicus University in Toruń, Collegium Medicum in Bydgoszcz, Department of Physiotherapy, Division \\ of Principles of Physiotherapy, Bydgoszcz, Poland \\ ${ }^{2}$ Academy of Physical Education and Sport in Gdańsk, Department of Mass Sport, Gdańsk, Poland \\ ${ }^{3}$ Academy of Physical Education and Sport in Gdańsk, Department of Tourism and Recreation Management, Gdańsk, \\ Poland
}

\begin{abstract}
Purpose: $\quad$ Irregularities in movable property of the spine affect a large part of society and the problem affects the people at an increasingly younger age. Classical massage is a form of mechanotherapy that affects the regulation of the work of muscles, joints, tendons and ligaments. The purpose of this study was to evaluate the efficacy of classical massage section of thoracolumbar spine to increase the mobility in these segments.

Material: $\quad$ The study was carried out on 36 healthy volunteers ( 20 women and 16 men) aged 21 to 27 years old (average age - 23.8) who were subjected to a series of five classical massages (according to strictly established protocol). In order to objectify the effects in all subjects before and after a series of treatments the following measurements were made: the fingers-floor test; the Otto -Wurna test; the straightening of the spine; lateral flexion of the spine; twist of the spine.

Results: $\quad$ A statistically important difference has been shown in the results of all tested variables before the first and after the last treatment of classical massage.

Conclusions: The results of personal research apply to young, healthy volunteers. It is worth to continue research into the effects of this form of therapy in the case of restrictions of movable tangible property, resulting from spinal pain syndromes.

Keywords: therapeutic, massage, mobility, spine, disorders, spinal pain.
\end{abstract}

\section{Introduction}

According to the Global Burden of Disease 2010 study, musculoskeletal loads are the fourth-rate health problem in the world and constitute $20-50 \%$ of the population. This problem affects most often: the lower spine, the cervical spine, shoulders and knees $[1,2]$.

Overloading of the spine can lead to disorders of its movable assets. Irregularities in movable property of the spine affect a large part of society and the problem affects the people at an increasingly younger age. The cause of their occurrence may be lifestyle, which unfortunately still prevails in our society. We are talking about chronic stress, sitting lifestyle and the lack of making physical activity, which in the first phase leads to disorders in the tension of muscles. Long-lasting muscle imbalance causes morphological and structural, that as a result, may lead to pathological static and dynamic stereotypes [37]. The muscles subjected to a long-term tension under static conditions become weaker over time, shortened and undergo painful contractures. In their area, some trigger points - places with high touch sensitivity may appear [8$10]$.

Ottawa Panel defined massage as "soft tissue and joint manipulation using the hands or a handheld device" [11, 12]. Massage improves blood circulation in the tissues, which streamlines the process of removing accumulated waste products and accelerates the regeneration processes. Increasing the activity of the receptors of the skin and the muscle contributes to increased pulsation and cerebral cortex, which normalizes the function of organs. Massage causes the normalization function of vegetative system (c) Radzimińska Agnieszka, Weber-Rajek Magdalena, LulińskaKuklik Ewelina, Piecka Paulina, Moska Waldemar, 2017 doi:10.15561/18189172.2017.0206 and increase the secretion of certain hormones such as endorphins and/or cortisol. An important aspect of the massage is its positive impact on the psyche of the patient, among others by toning effect on the nervous system [13$18]$.

The purpose of this study was to evaluate the efficacy of classical massage section of thoracolumbar spine to increase the mobility in these segments.

\section{Material and Methods}

Participants: The study was carried out on 36 healthy volunteers ( 20 women and $16 \mathrm{men}$ ) aged 21 to 27 years old (average age - 23.8) who were subjected to a series of five classical massages (according to strictly established protocol). Time of a single treatment was 25-30 minutes.

Research Design: In order to objectify the effects in all subjects, before and after a series of treatments, the following measurements have been made:

- The fingers-floor test (Thomayer). The purpose of this test is to determine the global ability to perform in front of the slope in the sagittal plane. The examined patient is instructed to stand on the platform, then asked to bend down with the straight knee joints. Then the distance from the third finger to the ground is measured.

- The Otto-Wurna test is used to measure the mobility of the thoracic spine. In order to perform the test, you must specify the location of the Th1, and then measure $30 \mathrm{~cm}$ (up to Th12). The patient performs the maximum bend down in front with straight knee joints. The difference, expressed in centimeters is a measure of the movable property of the test section of the spine. 
- $\quad$ Straightening the spine. The test is performed in a standing position. The measurement must be made by measuring the distance from the end of the xiphoid process to the pubic tubercles around the pubic bone. Then it is recommended to perform the maximum reaching of the trunk back with outstretched legs in the joints of the knee. In the marginal position the distance between the above-mentioned bone points is measured. The difference, expressed in centimeters is a measure of the movable property of the test section of the spine.

- The lateral flexion. The examined person is in a free position, with the upper limb of the test side reached back at the shoulder joint up to 90 degrees), hand based behind the head. The distance is measured from the top of the armpit to the highest place hip bone plate on the same side. After making a motion precisely in the frontal plane the distance shall be measured again. The difference in distance between the first and second measurement is a measure of the mobility of this section.

- $\quad$ Twists of the spine. The person is in the free position. The distance is measured from the end of the xiphoid process to the spike of the front upper hip. The tested person performs a twist of the trunk in the other side and the measurement shall be carried out again. The difference in distance between the first and second measurement is a measure of the mobility of this section.

Statistical Analysis: A statistical analysis of the collected material was carried out in PQstat program. The compliance of the variables schedules with normal distribution has been validated by test of Shapiro-Wolf. For the analysis of variables, a nonparametric test was used. Descriptive statistics were calculated for all variables. For the variables in the internal scale, which did not comply with the conditions of the normal distribution, the arithmetic average, minimum, maximum, median and upper and lower quartile were calculated. To evaluate the variability for dependent groups the Wilcoxon test was applied. For the level of statistical significance $p<0,05$ was adopted.

\section{Results}

Table 1 presents the descriptive statistics and the statistics value $\mathrm{Z}$ for the comparison of the results of all

Table 1. The test statistics values and p-value obtained in the test, Wilcoxon test at significance level $\alpha=0.05$ for all variables tested before the first and after a series of massages in the whole tested group.

\begin{tabular}{|c|c|c|c|c|c|c|c|c|}
\hline \multirow{2}{*}{ Variable } & & \multicolumn{6}{|c|}{ Descriptive statistics } & \multirow{2}{*}{$\begin{array}{l}\text { Test of } \\
\text { Wilcoxon } \\
\text { Statistics Z }\end{array}$} \\
\hline & & $\bar{x}$ & Min. & Max & Me & Q 1 & Q 3 & \\
\hline \multirow{2}{*}{$\begin{array}{l}\text { The fingers-floor } \\
\text { test }\end{array}$} & Before the massage & 0,04 & $-18,0$ & 12,0 & 1,5 & $-4,75$ & 3.63 & \multirow[b]{2}{*}{5,22} \\
\hline & $\begin{array}{l}\text { After a series of } \\
\text { massages }\end{array}$ & 6,00 & $-12,0$ & 27,0 & 5,75 & 1,75 & 9,50 & \\
\hline \multirow{2}{*}{$\begin{array}{l}\text { The Otto-Wurna } \\
\text { test (bending) }\end{array}$} & Before the massage & 2,03 & 0,50 & 5,00 & 2,00 & 1,00 & 3,00 & \multirow{2}{*}{5,12} \\
\hline & $\begin{array}{l}\text { After a series of } \\
\text { massages }\end{array}$ & 3,21 & 1,50 & 6,00 & 3,00 & 2,00 & 4,13 & \\
\hline \multirow[b]{2}{*}{ Straightening up } & Before the massage & 6,28 & 3,00 & 13,0 & 6,00 & 4,88 & 7,00 & \multirow[b]{2}{*}{5,16} \\
\hline & $\begin{array}{l}\text { After a series of } \\
\text { massages }\end{array}$ & 8,89 & 4,50 & 15,50 & 7,50 & 7,50 & 11,00 & \\
\hline \multirow{2}{*}{$\begin{array}{l}\text { Lateral flexion in } \\
\text { the right }\end{array}$} & Before the massage & 7,69 & 3,00 & 11,0 & 8,00 & 6,00 & 9,00 & \multirow[b]{2}{*}{5,24} \\
\hline & $\begin{array}{l}\text { After a series of } \\
\text { massages }\end{array}$ & 9,26 & 7,00 & 15,0 & 9,75 & 9,00 & 11,25 & \\
\hline \multirow{2}{*}{$\begin{array}{l}\text { Lateral flexion in } \\
\text { the left }\end{array}$} & Before the massage & 7,92 & 5,00 & 12,00 & 8,00 & 6,38 & 9,00 & \multirow[b]{2}{*}{5,24} \\
\hline & $\begin{array}{l}\text { After a series of } \\
\text { massages }\end{array}$ & 10,44 & 7,00 & 15,00 & 9,00 & 8,88 & 11,63 & \\
\hline \multirow[b]{2}{*}{ Twisting right } & Before the massage & 3.46 & 1,50 & 6,00 & 3,50 & 2,00 & 4,13 & \multirow[b]{2}{*}{5,05} \\
\hline & $\begin{array}{l}\text { After a series of } \\
\text { massages }\end{array}$ & 4,88 & 2,50 & 9,00 & 4,50 & 3,50 & 6,00 & \\
\hline \multirow[b]{2}{*}{ Twisting left } & Before the massage & 3,54 & 1,50 & 6,00 & 3,50 & 2,00 & 4,13 & \multirow[b]{2}{*}{5,12} \\
\hline & $\begin{array}{l}\text { After a series of } \\
\text { massages }\end{array}$ & 4,13 & 3,00 & 9,00 & 4,50 & 4,50 & 6,25 & \\
\hline
\end{tabular}

Note: $\bar{x}$ - aarithmetic average; Min. - minimum; Max - maximum; Me-the median; Q 1-the first quartile; Q 3-the third quartile; $Z$ - the Wilcoxon test value; $p$ - significance level $(<0,001)$. 
tested variables before the first or after the last treatment of classical massage.

By comparing the value of Wilcoxon test statisticsbased on the significance level of $\alpha=0.05$, it was found that there is a statistically important difference in the results of all tested variables before the first and after the last treatment of classical massage.

\section{Discussion}

In literature, there are few reports on the evaluation of the effectiveness of classical massage in the treatment of spinal mobility. Most of these studies relate to the effectiveness of this form of therapy in the treatment of chronic spinal pain syndromes. The authors of this analysis realize that the results cited in the discussion of the study cannot directly correspond to the results of personal research, which were conducted on healthy young volunteers with no chronic pain disorders of the spine. Nevertheless, the results of personal research are encouraging, so you might want to incorporate in a discussion on assessing the effectiveness of this form of therapy for chronic pain syndrome of the spine, the more that the test results available in the literature are not unambiguous and as mentioned earlier, they are few.

Ćwirlej et al. [19] conducted a study, the purpose of which was to assess the effects of the therapeutic massage in patients with spinal pain, and, in particular, its impact on the reduction of pain intensity and improved ranges of mobility of the spine. To the test group 53 people have been enrolled, who have undergone a series of massage treatments (the examined patients during this time were treated only with this kind of therapy). All the people before and after the therapy have had assessed the severity of spine pain (VAS scale) and the mobility of the spine (a linear measurement, the range of flexion, extension, lateral flexion and twisting of the spine). A clear analgesic therapeutic massage and its positive impact on the improvement of the movable ranges of the spine have been shown.

Zgorzalewicz-Ferguson et al. [20] compared the effectiveness of the two methods: massage and therapy on patients with chronic spinal pain syndrome formed as a result of degenerative changes. The study included 60 patients, who were divided into two groups: in the group I- a classical massage was performed, in the group II - magnetic therapy. In order to objectify the therapy effects applied: scale VAS, mobility measurements and evaluation of the degree of disability of patients on a modified scale Oswestry (ODI). Test results showed no significant differences in the effectiveness of the methods used. After the application of a massage or a magnet therapy primarily pain and disability ailments have significantly decreased and the mobility of the spine has only slightly improved.

Kałużna et al. [21] the study included a group of 80 patients with chronic pains, ailments of the spine, for whom a series of 10 treatments of classical massage have been carried out. Before and after the therapy in all patients: the Otta, Schober test and pain assessment VAS scale was performed. Test results have shown the effectiveness of classical massage in the aspect of reducing the level of pain, and improving the range of mobility of the spine.

Hernandez-Reif al. [22] the research took twentyfour people with lumbosacral spine pain syndrome. In all patients, the treatment performed classical massage (30-minute sessions, twice a week for five weeks). In order to objectify efficacy: the severity of the pain, the occurrence of symptoms of depression, anxiety, insomnia and the level of stress hormones were evaluated. Comparison group comprised patients who applied gymnastics. As a result of studies more favorable results have been shown in patients, for whom therapeutic massage was used, compared to a group that was involved in gymnastics. After a series of treatments to therapeutic massage: a decreased pain, reduced severity of symptoms of anxiety and depression, the improvement of sleep quality, increasing the range of motion of flexion of vertebral column, higher levels of dopamine and serotonin have been observed.

Bell [23] evaluated the effectiveness of massage, as a form of therapy that increases the mobility of the spine and reducing the severity of pain in a patient with lower back pains, ailments and symptoms of sciatica (pain radiating to right lower limb). The patient was assigned to 45-minute massage session, once a week, for a period of 10 weeks. Massage treatment was carried out in the area of the spine, pelvis, thighs and crus by orderly protocol. After the therapy a greater patient's activity has been shown, measured by the scale of the ADSL (Activities of daily living).

Kamali et al. [24] compared the effectiveness of therapeutic massage and physical treatments in the treatment of subacute and chronic pain spine L-S. 30 patients were divided randomly into two groups: Group I have had massage performed, Group II physical treatments (TENS, sonotherapy, vibration therapy). The two groups have also undergone stretching exercises for the muscles of the ischiopubic-varicose and paraspinal posture stabilization exercises. In all patients, before and after the therapy: severity of pain by using a numerical scale (Numerical Rating Scale), disability by means of a questionnaire ODI (Oswestry Disability Index), the range of motion of flexion of vertebral column using the Schober test were evaluated. Statistical analysis of the test results showed that the treated group therapy, compared to the group treated physical therapy significantly reduced the intensity of the pain and disability of patients $(\mathrm{p}=0.015$, $\mathrm{p}=0.013$ ). While no statistically significant differences between the groups in the Schober test results.

Chochowska et al. [25] were testing patients over the age of 65 with chronic pain syndrome in the lumbosacral section. 10 classical back massage (20 min.), and 10 vibration massage 24 drain points $(0,5 \operatorname{minx} 24=12$ min.) were performed. Before and after the therapy they have studied: the intensity of the pain by using visual analog scale: and pain scale Laitinen; efficiency: by using the Questionnaire of Disability and RolandMorris Questionnaire of Disability; soft tissue palpation 
tenderness; mobility of the thorax and spine; mood: with the Geriatric Depression Scale. After finishing series of 10 treatments we obtained statistically significant pain reduction, improved efficiency, decrease in soft tissue palpation tenderness, improved mood, and a slight increase in the mobility of the spine.

Dr. Andrea Furlan of the University of Toronto, the Coordinator of POWAP (Practice Based on Reliable and Up-To-Date Publications - in Polish.) at the Institute for work and health, reviewed the systematic studies assessing the efficacy of therapeutic massage vs. other therapies in the treatment of chronic spinal pain syndromes. The author reviewed the databases MEDLINE, EMBASE, CINAHL from the beginning of their existence by 2008 . The review includes the 13 studies, randomized or quasirandomized controlled trials, referring to the efficacy of massage in treatment of chronic spinal pain syndromes. As a result of that review, Furlan et al. [26] have drawn the following conclusions:

\section{References}

1. Picavet HS, Hazes JM. Prevalence of self-reported musculoskeletal diseases is high. Annals of the Rheumatic Diseases, 2003; 62:644-650.

2. Hoy DG, Smith E, Cross M, Sanchez-Riera L, Blyth MS, Buchbinder R. Reflecting on the global burden of musculoskeletal conditions: lessons learnt from the Global Burden of Disease 2010 Study and the next steps forward. Annals of the Rheumatic Diseases, 2015; 74:4 - 7.

3. Lee J, Yoo W.G The mechanical effect of anterior pelvic tilt taping on slump sitting by seated workers. Industrial Health ,2011;49(4):403-409.

4. Smith A, O'Sullivan P, Straker L. Classification of sagittal thoraco-lumbo-pelvic inflammatory alignment of the adolescent spine in standing and its relationship to low back pain. Spine (Phila Pa 1976). 2008; 33 (19): 2101-7.

5. Fedorenko SN, Lazarieva EB, Kormiltsev VV. The using of aquafitnes in the physical rehabilitation of patients with vertebral pathology. Physical Education of Students, 2012; 3:112-115.

6. Desyatnikov GO. Comparative analysis of development of force of muscles of the back for students, occupying in different sections. Physical Education of Students, 2011; $1: 56-58$

7. Weber-Rajek M, Lulińska-Kuklik E, Orłowska K, Czerniachowska I, Radzimińska A, Moska W. Evaluating the effectiveness of various forms of physical therapy in low back pain treatment, Trends Sport Sci. 2016; 23 (3): 147-154.

8. Defrin R. Compression at myofascial trigger points for the management of acute low back pain. European Journal of Pain, 2015; 19 (8): 1057-8.

9. Takamoto K, Bito I, Urakawa S, Sakai S, Kigawa M, Ono T, Nishijo H. Effects of compression at myofascial trigger points in patients with acute low back pain: A randomized controlled trial. European Journal of Pain, 2015;19 (8): 1086-96.

10.Gerwin RD. Myofascial Trigger Point Pain Syndromes. Started in Neurology, 2016; 36 (5): 469-473.

11.Brosseau L, Wells GA, Poitras S, Tugwell P, Casimiro L, Novikov M. Ottawa Panel evidence-based clinical practice guidelines on therapeutic massage for low back pain. Journal
- massage can be an effective treatment for chronic spinal pain syndromes, especially when combined with exercise and patient education;

- the evidence suggest that the acupuncture massage is more effective than the classical massage, but this requires confirmation;

- There is a need for further research on the effectiveness of this form of therapy.

\section{Conclusions}

1. The findings have shown that classical massage increases the mobility of the spine.

2. The results of personal research apply to young, healthy volunteers. It is worth to continue research into the effects of this form of therapy in the case of restrictions of movable tangible property, resulting from spinal pain syndromes.

\section{Conflict of interests}

The authors declare that there is no conflict of interests. of Bodywork and Movement Therapies, 2012; 16:424-455.

12.Brosseau L, Wells GA, Poitras S, Tugwell P, Casimiro L, Novikov M. Ottawa Panel evidence-based clinical practice guidelines on therapeutic massage for low back pain. Journal of Bodywork and Movement Therapies, 2012; 16:424-455.

13.Lewis M, Johnson M. The clinical effectiveness of therapeutic massage for musculoskeletal pain: a systematic review. Physiotherapy, 2006; 92 (3): 146-58.

14.Bervoets DC, Luijsterburg PA, Alessie JJ, Buijs MJ, Verhagen AP. Massage therapy has short-term benefits for people with common musculoskeletal disorders compared to no treatment: a systematic review. The journal of Physiotherapy, 2015; 61 (3): 106-16.

15.Crane JD, Ogborn DI, Cupido C, Melov S, Hubbard A, Bourgeois JM. Massage therapy attenuates inflammatory signaling after exercise-induced muscle damage. Science Translational Medicine, 2012;4(119):119-123.

16.Torres R, Ribeiro F, Alberto Duarte J, Cabri JM. Evidence of the physiotherapeutic interventions used currently after exercise-induced muscle damage: systematic review and meta-analysis. Physical Therapy in Sport, 2012;13(2):10114.

17.Moyer CA, Rounds J, Hannum JW. A meta-analysis of massage therapy research. Psychological Bulletin, 2004;130:3-18.

18.Field TM. Massage therapy effects. American Psychologist, 1998;53:1270-1281.

19.Ćwirlej A, Ćwirlej A, Maciejczak A. Effects of the medical massage in the treatment of back pain Review of Medical University of Rzeszow, 2007; 3: 253-257. [in Polish]

20.Zgorzalewicz - Stachowiak M, Jopek M, Smajdor T. The use of classical massage and magnetotherapy in the treatment of chronic pain syndromes of the lumbar spine. Problems of the Family Medicine, 2014; 3 (43): 28-34. [in Polish]

21.Kałużna A, Kałużny K, Kochański B, Kluska K, Płoszaj O, Zukow W. Evaluation of the results of treatment of chronic back pain in the lumbo-sacral via a classical massage. Journal of Education, Health and Sport, 2015; 5 (9): 57786. [in Polish]

22.Hernandez-Reif M, Field T, Krasnegor J, Theakston H. Lower back pain is reduced and range of motion increased 
after massage therapy. International Journal of Neuroscience, 2001;106 (3-4):131-45.

23.Bell J. Massage therapy helps to increase range of motion, decrease pain and assist in healing a client with low back pain and sciatica symptoms. Journal of Bodywork and Movement Therapies, 2008; 12(3):281-9.

24.Kamali F, Panahi F, Ebrahimi S, Abbasai L. Comparison between massage and routine physical therapy in women with sub-acute and chronic nonspecific low back pain. Journal of Back and Musculoskeletal Rehabilitation, 2014;27(4):47580 .
25.Chochowska M, Marcinkowski JT, Rąglewska P, Babiak J. Masaż klasyczny i masaż wibracyjny punktów spustowych bólu w leczeniu zespołu bólowego kręgosłupa z towarzyszącym mu obniżeniem nastroju - u osób starszych [Swedish massage therapy and vibration massage of trigger points in elderly patients with low back pain and depression]. Problemy Higieny i Epidemiologii, 2011; 92(3): 428-435. [in Polish]

26.Furlan AD, Imamura M, Dryden T, Irvin E. Massage for lowback pain. Cochrane Database Systematic Reviews, 2008; 8(4):CD001929.

\section{Information about the authors:}

Radziminska Agnieszka; http://orcid.org/0000-0002-3718-6350; radziminska@cm.umk.pl; Collegium Medicum in Bydgoszcz, Nicolaus Copernicus University in Torun; ul. Technikow 3, 85-801 Bydgoszcz, Poland.

Weber-Rajek Magdalena; http://orcid.org/0000-0003-4435-9624; magdawz@cm.umk.pl; Collegium Medicum in Bydgoszcz, Nicolaus Copernicus University in Torun; ul. Technikow 3, 85-801 Bydgoszcz, Poland.

Lulinska-Kuklik Ewelina; http://orcid.org/0000-0002-3094-7241; ewelina.lulinska@awfis.gda.pl; Academy of Physical Education and Sport in Gdansk; ul. Kazimierza Gorskiego 1, 80-336 Gdansk, Poland.

Piecka Paulina; http://orcid.org/0000-0003-4739-5487; zpfizjoter@cm.umk.pl; Collegium Medicum in Bydgoszcz, Nicolaus Copernicus University in Torun; ul. Technikow 3, 85-801 Bydgoszcz, Poland.

Moska Waldemar; http://orcid.org/0000-0002-5232-4598; waldemar.moska@awfis.gda.pl; Academy of Physical Education and Sport in Gdansk; ul. Kazimierza Gorskiego 1, 80-336 Gdansk, Poland.

Cite this article as: Radzimińska Agnieszka, Weber-Rajek Magdalena, Lulińska-Kuklik Ewelina, Piecka Paulina, Moska Waldemar. The impact of classical massage on spine mobility. Pedagogics, psychology, medical-biological problems of physical training and sports, 2017;2:82-86. doi:10.15561/18189172.2017.0206

The electronic version of this article is the complete one and can be found online at: http://www.sportpedagogy.org.ua/index.php/PPS/issue/archive

This is an Open Access article distributed under the terms of the Creative Commons Attribution License, which permits unrestricted use, distribution, and reproduction in any medium, provided the original work is properly cited (http://creativecommons.org/licenses/by/4.0/deed.en).

Received: 26.01.2017

Accepted: 31.01.2017; Published: 30.04.2017 